\title{
Maintaining Growth of Aquatic Morning Glory under Drought Condition by Paenibacillus sp. BSR $1-1$
}

\author{
Khanitta Somtrakoon ${ }^{1, *}$, Aphidech Sangdee ${ }^{1}$ and Waraporn Chouychai ${ }^{2}$ \\ ${ }^{I}$ Department of Biology, Faculty of Science, Mahasarakham University, Maha Sarakham 44150, Thailand \\ ${ }^{2}$ Biology Program, Department of Science, Faculty of Science and Technology, \\ Nakhonsawan Rajabhat University, Nakhon Sawan 60000, Thailand
}

('Corresponding author's e-mail: khanitta.s@msu.ac.th)

Received: 6 October 2020, Revised: 3 May 2021, Accepted: 30 May 2021

\begin{abstract}
Paenibacillus sp. $\mathrm{BSR}_{1-1}$ is a plant growth-promoting bacteria with the ability to produce indole-3acetic acid, exopolysaccharide and ammonia. This bacterial isolate grew well under low water potential, with the concentration of polyethylene glycol (PEG) ranging from $20-30 \%(\mathrm{w} / \mathrm{v})$. Paenibacillus sp. $\mathrm{BSR}_{1-1}$ was a suitable bio-inoculant to maintain the growth of aquatic morning glory cultivated under drought conditions in this study. Inoculation of Paenibacillus sp. $\mathrm{BSR}_{1-1}$, as immobilized cells in coconut husk, sawdust or rice straw, tended to stimulate root growth of aquatic morning glory cultivated under drought conditions. The specific root lengths of aquatic morning glory grown under drought conditions were $1.31,2.86$, and $1.76 \mathrm{~m} / \mathrm{g}$ in the presence of Paenibacillus $\mathrm{sp}$. BSR $\mathrm{BS}_{1-1}$ immobilized in coconut husk, sawdust or rice straw, respectively. Root length and root dry weight of aquatic morning glory planted under drought conditions in the presence of Paenibacillus sp. BSR $1-1$ were around $17.71-18.08 \mathrm{~cm}$ and $0.16-0.28 \mathrm{~g}$, respectively. Meanwhile, the root length and root dry weight of aquatic morning glory planted under drought conditions in the absence of Paenibacillus sp. BSR B-1 $_{1}$ were only $10.62-13.54 \mathrm{~cm}$ and $0.04-0.11 \mathrm{~g}$, respectively. In addition, the root morphology of aquatic morning glory planted under drought conditions in the presence of Paenibacillus sp. $\mathrm{BSR}_{1-1}$ was more branched and longer than that without Paenibacillus sp. BSR B-1 $_{1}$ inoculation. However, the inoculation of Paenibacillus sp. BSR B $_{1-1}$ to soil did not stimulate shoot growth of aquatic morning glory planted under both normal and drought conditions.
\end{abstract}

Keywords: Aquatic morning glory, Drought stress, Immobilized cells, Plant growth-promoting bacteria

\section{Introduction}

Nowadays, soil fertility in agricultural land is not sufficient to produce food for the increasing world population. Moreover, climate change is a phenomenon that decreases the fertility of the area by increasing the frequency of droughts [1,2]. Drought stress is a major agricultural obstacle that reduces crop yield in many regions of the world, including Southeast Asia, such as Thailand $[3,4]$. Due to climate change, the temperature in Thailand has increased by about $1.04-1.80{ }^{\circ} \mathrm{C}$ per century and there has been a decrease in annual rainfall over the past 3 decades [3]. Drought is a serious problem and drought areas were reported in almost all parts of Thailand [5]. Drought destroys agricultural activity in several ways, including soil water deficiency, dehydration in plants, retardation of growth in plants and low agricultural productivity [6].

Many plant growth parameters decrease under drought stress, such as seed germination, seedling strength, chlorophyll content, leaf size, stem enlargement and root generation. Drought stress also decreases water-soluble nutrient diffusion to the plant roots [7,8]. Severe effects of drought results in decreasing plant productivity and plant death [9]. Various methods to resolve the drought problem in agricultural areas include using cropping systems that are less water-dependent, replacement of plant species with ones that require less water and using appropriate irrigation systems [10]. Moreover, the application of plant growth-promoting bacteria is a proposed way to alleviate drought stress in plants through improved soil quality and to promote the growth of plants under drought stress [11]. The possible mechanisms of plant growth-promoting bacteria to stimulate the growth of plants under drought stress include exopolysaccharides (EPS) production, which helps increase the soil water holding capacity [1], 
indole-3-acetic acid production, which improves root growth in plants [1], 1-aminocyclopropane-1carboxylate (ACC) deaminase production, which reduces stress from ethylene on plants and induction of the accumulation of osmolyte and antioxidant activity [8].

Using IAA-producing bacteria to alleviate drought stress and promote root growth of plants under drought stress was of interest in this study because plant roots were sensitive to drought stress and their growth was limited by drought stress before other plant organs [10]. Increasing abscisic acid and the ethylene level under drought stress usually limits the production of auxins in plants [7]. Thus, application of IAA-producing bacteria may be compensated for by endogenous auxin and to improve the growth of the plant under drought stress by modification of the root architecture (increasing the number of root tips and root surface area), which contributed to the mineral and water uptake by the plants $[1,12]$. IAAproducing bacteria have been reported to promote the growth and development of roots in plants grown under drought stress. For example, Enterobacter sp. (16i) and Bacillus sp. (12D6) with the abilities of IAA and salicylic acid production could change the root system architecture of wheat (Triticum aestivum) and maize (Zea mays) [12]. Enterobacter sp. (16i) and Bacillus sp. (12D6) promoted root branching in wheat and both bacteria promoted root elongation, increasing the root area and number of root tips in maize [12]. Other bacteria that promote the growth of plants under drought stress include Azotobacter chroococcum 67B and Azotobacter chroococcum 76A. Both bacteria can produce siderophores, ACC deaminase and IAA. Azotobacter chroococcum 67B and Azotobacter chroococcum 76A could decrease stress in tomatoes planted under drought stress [13].

This study focuses on using IAA-producing bacteria, Paenibacillus sp. $\mathrm{BSR}_{1-1}$ (similarity to Paenibacillus polymyxa of about $97 \%$ based on 16s rDNA sequence) to relieve drought stress in aquatic morning glory (Ipomoea aquatic Forsk.) cultivated under drought conditions. Aquatic morning glory is used as a model plant in this study because it is usually found in high soil moisture areas, including the edge of stagnant streams and ponds [14,15]. Thus, drought conditions may affect the growth of aquatic morning glory by decreasing their growth, resulting in dwarfism and limiting their yield production. The objective of this study was to investigate the ability of Paenibacillus sp. BSR $_{1-1}$ cells immobilized in coconut husk, sawdust and rice straw to stimulate the growth of aquatic morning glory under drought conditions. The findings of this study will be useful to improve agricultural systems under drought conditions in the future.

\section{Materials and methods}

\section{Preparation of aquatic morning glory seedlings}

The seeds of aquatic morning glory were obtained from Chuayongseng Seed Co. Ltd., Bangkok, Thailand. Surface sterilization of aquatic morning glory was done before planting (seeds were soaked in $0.6 \%$ hypochlorite for $5 \mathrm{~min}$ and rinsed with sterilized distilled water for $1 \mathrm{~min}, 3$ times). Then, 5 aquatic morning glory seeds were planting in experimental pots containing non-sterilized soil. After seed germination, 3 healthy seedlings with similar sizes were allowed to grow in the experimental pot (3 seedlings per 1 experimental pot). The other seedlings in each experimental pot were removed.

\section{Preparation of free cells of Paenibacillus sp. BSR $_{1-1}$}

Paenibacillus sp. $\mathrm{BSR}_{1-1}$ was cultured in nutrient broth for $24 \mathrm{~h}$ at room temperature and this cell suspension was used as inoculum for the free cells. Coconut husk-, sawdust-, and rice straw-immobilized cells of Paenibacillus sp. BSR 1-1 $_{1}$ were prepared according to the method described in Somtrakoon et al. [16]. These materials were cut into small pieces $\left(5 \times 5 \mathrm{~cm}^{2}\right)$. Small pieces of coconut husk, sawdust and rice straw were sterilized by autoclaving at $121{ }^{\circ} \mathrm{C}$ for $15 \mathrm{~min}$ and were cool under room temperature. Then they were damped in the cell suspension of Paenibacillus sp. $\mathrm{BSR}_{1-1}$ for $3 \mathrm{~h}$ to give immobilized cells of Paenibacillus sp. BSR 1-1 $_{1}$ in agricultural materials. The initial number of bacterial cells from the plate count method for the coconut husk, sawdust and rice straw were 4.9, 5.0 and $6.0 \mathrm{log} \mathrm{cfu} / \mathrm{g}$, respectively. The plate count method was done following the method described by the U.S. Food and Drug Administration [17]

\section{Plant growth-promoting characteristics of Paenibacillus $\mathbf{s p}$. BSR $\mathbf{B}_{1-1}$}

Preliminary screening for exopolysaccharide production was done by the method described by Lakshminarayanan [18]. Briefly, a $24 \mathrm{~h}$ cell suspension of Paenibacillus sp. BSR $1-1$ was streaked on aniline blue agar (ABA) medium and incubated for $48 \mathrm{~h}$ at $30{ }^{\circ} \mathrm{C}$. A positive test for exopolysaccharide ( $\beta$-glucan) production was observed by an intense blue color colony. 
$\mathrm{NH}_{3}$ production was done by the method described by Ahmad et al. [19]. A $24 \mathrm{~h}$ cell suspension of Paenibacillus sp. $\mathrm{BSR}_{1-1}$ was transferred to $10 \mathrm{~mL}$ of peptone water and incubated in a culture tube at $30{ }^{\circ} \mathrm{C}$ for $48 \mathrm{~h}$. Then $0.5 \mathrm{~mL}$ Nessler's reagent was poured into the incubation tube. A positive test for $\mathrm{NH}_{3}$ production was observed by the development of a brown color.

The growth of Paenibacillus sp. $\mathrm{BSR}_{1-1}$ under low water potential was tested by the method described by Chandra et al. [20]. A $24 \mathrm{~h}$ cell suspension of Paenibacillus sp. BSR $1-1$ was transferred to nutrient broth plus 20, 25 and $30 \%$ polyethylene glycol (water potential at $-0.5,-0.75$ and $-1.0 \mathrm{MPa}$ ). Nutrient broth without polyethylene glycon served as a control. Then the culture tubes were incubated for $24 \mathrm{~h}$ at $30^{\circ} \mathrm{C}$. Growth of the bacterial isolate was determined by optical density with a spectrophotometer at $600 \mathrm{~nm}$.

\section{Experimental design}

The experiment was performed under a factorial completely randomized design with 2 (normal condition, drought condition) $\times 2$ factors (material with and without Paenibacillus sp. BSR $_{1-1}$ immobilized in agricultural materials) and each treatment was performed for 7 replicates and there were 4 treatments for each material (coconut husk, sawdust or rice straw).

Coconut husk: Treatment $1=$ normal condition + coconut husk, Treatment $2=$ normal condition + Paenibacillus sp. BSR B-1 $_{1}$ immobilized in coconut husk, Treatment $3=$ drought condition + coconut husk,

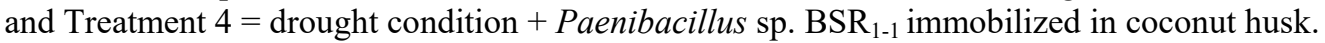

Sawdust: Treatment $1=$ normal condition + sawdust, Treatment 2 = normal condition + Paenibacillus sp. BSR $_{1-1}$ immobilized in sawdust, Treatment $3=$ drought condition + sawdust, and Treatment $4=$ drought condition + Paenibacillus sp. BSR $_{1-1}$ immobilized in sawdust.

Rice straw: Treatment $1=$ normal condition + rice straw, Treatment 2 = normal condition + Paenibacillus sp. $\mathrm{BSR}_{1-1}$ immobilized in rice straw, Treatment $3=$ drought condition + rice straw, and Treatment $4=$ drought condition + Paenibacillus sp. BSR $_{1-1}$ immobilized in rice straw.

The first day of the experiment was the first day of bacterial inoculation. Seven-day-old aquatic morning glory seedlings were inoculated and planted in experimental pots containing $1 \mathrm{~kg}$ of soil for 60 days after inoculation. Each $7 \mathrm{~g}$ of coconut husk, sawdust and rice straw or cells of Paenibacillus sp. $\mathrm{BSR}_{1-1}$ immobilized in coconut husk, sawdust and rice straw were plated on the surface of each experimental pot on the first day of the experiment. Water was spilled into the experimental pot every day to keep the normal soil moisture content at $20 \mathrm{~mL} /$ pot. For the drought condition, the water was added at $20 \mathrm{~mL} /$ pot every other day. The position of the experimental pot was changed every week to reduce the effect from the sunlight received. Plant samples were collected on day 60 of the experiment for analysis of the plant growth parameters, including shoot length, root length, shoot weight, root weight and chlorophyll contents in the leaves. The chlorophyll content in the leaves was determined according to the method described in Huang et al. [21].

\section{Statistical analysis}

A two-way ANOVA and Least Square Difference (LSD) were used for variance analysis and pairwise comparison.

\section{Results and discussion}

The results in Table 1 show that Paenibacillus sp. BSR $_{1-1}$ is an IAA, ammonia and exopolysaccharide-producing bacteria (Figure 1) and it could grow at a low water potential. Paenibacillus sp. $\mathrm{BSR}_{1-1}$ grew well at a water potential of $-0.5 \mathrm{MPa}(20 \% \mathrm{PEG})$ and a decrease in the water potential to -0.75 and $-1.0 \mathrm{MPa}$ did not affect the growth of Paenibacillus $\mathrm{sp}$. BSR $\mathrm{BS}_{1-1}$. The optical density of Paenibacillus sp. BSR B $_{1-1}$ when growing at a water potential of -0.75 (25\% PEG) and -1.0 $\mathrm{MPa}(30 \%$ PEG) was not significantly different from the optical density of Paenibacillus sp. BSR $1-1$ when growing in culture media without PEG (Table 1).

Table 1 Plant growth-promoting characteristics of Paenibacillus sp. BSR 1-1 $_{\text {. }}$

\begin{tabular}{|c|c|c|c|c|c|c|c|}
\hline \multirow{2}{*}{$\underset{\text { production }^{\mathbf{A}}}{\text { IAA }}$} & \multirow{2}{*}{$\begin{array}{c}\text { Phosphate } \\
\text { solubilization }^{\mathrm{A}}\end{array}$} & \multirow{2}{*}{$\begin{array}{l}\text { B-glucan } \\
\text { production }\end{array}$} & \multirow{2}{*}{$\begin{array}{c}\mathrm{NH}_{3} \\
\text { production }\end{array}$} & \multicolumn{4}{|c|}{ Drought tolerance (O.D. $600 \mathrm{~nm})^{\mathrm{B}}$} \\
\hline & & & & $0 \%$ PEG & $20 \%$ PEG & $25 \%$ PEG & $30 \%$ PEG \\
\hline$+(\mathrm{ND})$ & - (ND) & + & + & $0.45 \pm 0.05 b$ & $0.73 \pm 0.04 a$ & $0.48 \pm 0.02 b$ & $0.42 \pm 0.02 b$ \\
\hline
\end{tabular}




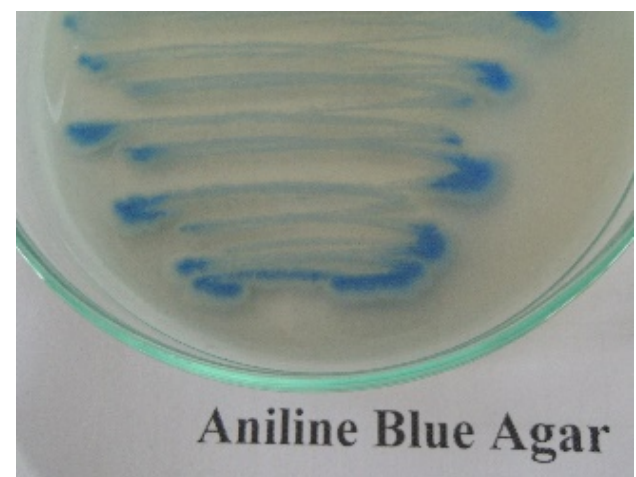

Figure 1 Colony of Paenibacillus sp. BSR 1-1 $_{1}$ giving blue color when grown on ABA medium for $48 \mathrm{~h}$.

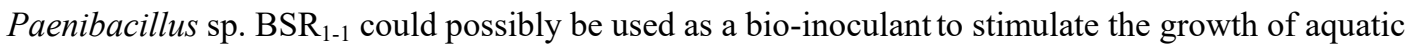
morning glory grown under drought conditions because it produces IAA, exopolysaccharides and enables growth at low water potential. In this study, Paenibacillus sp. BRS $\mathrm{Br}_{1-1}$ was immobilized on 3 types of natural materials (coconut husk, sawdust and rice straw) before the addition of the bacterial cells to the soil. Immobilization of the cells was expected to protect the bacterial cells from environmental stress in soil, including suboptimal temperature, suboptimal soil moisture, protozoa predators and competition from indigenous soil microorganisms [22-26]. Thus, cells of Paenibacillus sp. $\mathrm{BRS}_{1-}$ immobilized on agricultural materials in this study was expected to improve the survival of the bacterial cells. The results of this study revealed that immobilized Paenibcillus sp. $\mathrm{BRS}_{1-1}$ in coconut husk, sawdust and rice straw have similar trends to stimulate the growth of aquatic morning glory (Figures 2 - 4). Immobilized Paenibacillus sp. $\mathrm{BRS}_{1-1}$ could stimulate only root growth of aquatic morning glory. The results revealed that Paenibacillus sp. $\mathrm{BRS}_{1-1}$ immobilized on coconut husk could stimulate root growth of aquatic morning glory grown under normal and drought conditions. The results revealed that the root-shoot ratio, root length, root fresh weight and root dry weight of aquatic morning glory grown under drought conditions in the presence of chopped coconut husk immobilized Paenibacillus sp. BRS 1-1 $_{1}$ were 0.40 , $17.71 \mathrm{~cm}, 5.55$ and $0.28 \mathrm{~g}$, respectively. Meanwhile, the root-shoot ratio, root length, root fresh weight and root dry weight of aquatic morning glory grown under drought conditions in the absence of immobilized Paenibacillus sp. BRS $\mathrm{B}_{1-1}$ were $0.18,13.12 \mathrm{~cm}, 1.66$ and $0.08 \mathrm{~g}$, respectively. The shoot fresh weight, shoot dry weight, number of shoots per plant and number of leaves per plant of aquatic morning glory grown under normal conditions or under drought conditions in the presence or absence of Paenibacillus sp. $\mathrm{BRS}_{1-1}$ did not significantly differ.

The addition of Paenibacillus sp. BRS $\mathrm{B}_{1-1}$ either immobilized in sawdust or rice straw tended to increase the root growth of aquatic morning glory grown under drought conditions (Figures 3 and 4). The root length, root fresh weight and root dry weight of aquatic morning glory under drought conditions were $16.02 \mathrm{~cm}, 3.97$ and $0.16 \mathrm{~g}$ in the presence of Paenibacillus sp. BSR $\mathrm{B}_{1-1}$ immobilized on sawdust. The root length, root fresh weight and root dry weight of aquatic morning glory under drought conditions were only $10.62 \mathrm{~cm}, 0.90$ and $0.04 \mathrm{~g}$ in the presence of sawdust free cells of Paenibacillus sp. BSR $1-1$. Inoculation of Paenibacillus sp. $\mathrm{BSR}_{1-1}$ immobilized on rice straw also improved the root growth of aquatic morning glory grown under drought conditions. The root length, root fresh weight and root dry weight of aquatic morning glory under drought conditions were $18.08 \mathrm{~cm}, 4.14$ and $0.22 \mathrm{~g}$ in the presence of Paenibacillus sp. $\mathrm{BSR}_{1-1}$ immobilized on rice straw. The root length, root fresh weight and root dry weight of Ipomoea aquatic under drought conditions were only $13.54 \mathrm{~cm}, 1.77$ and $0.11 \mathrm{~g}$ in the presence of rice straw without Paenibacillus sp. BSR ${ }_{1-1}$. On the other hand, inoculation of Paenibacillus sp. BSR $\mathrm{BS}_{1-1}$ did not improve the shoot growth of aquatic morning glory under normal conditions or drought conditions either immobilized on sawdust or rice straw. 


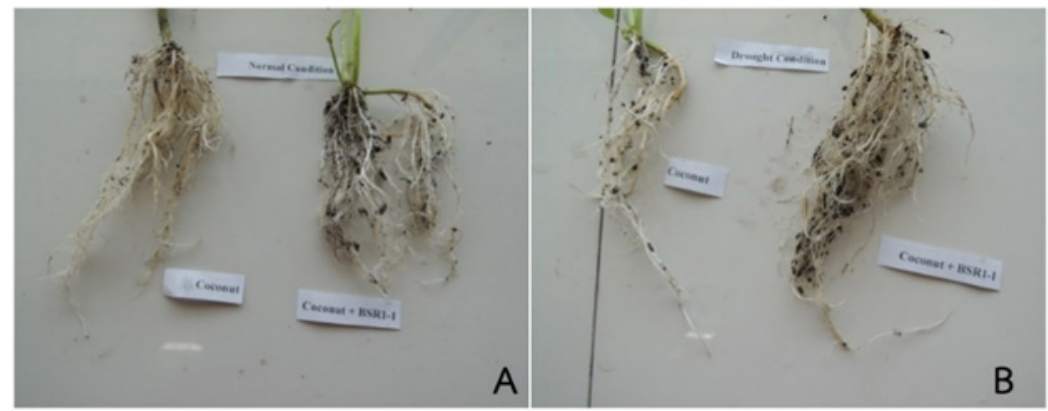

Figure 2 Characteristics of roots of aquatic morning glory grown under normal A) and drought conditions

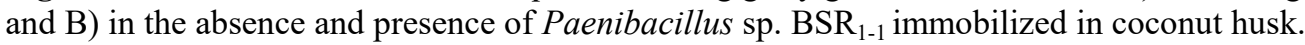

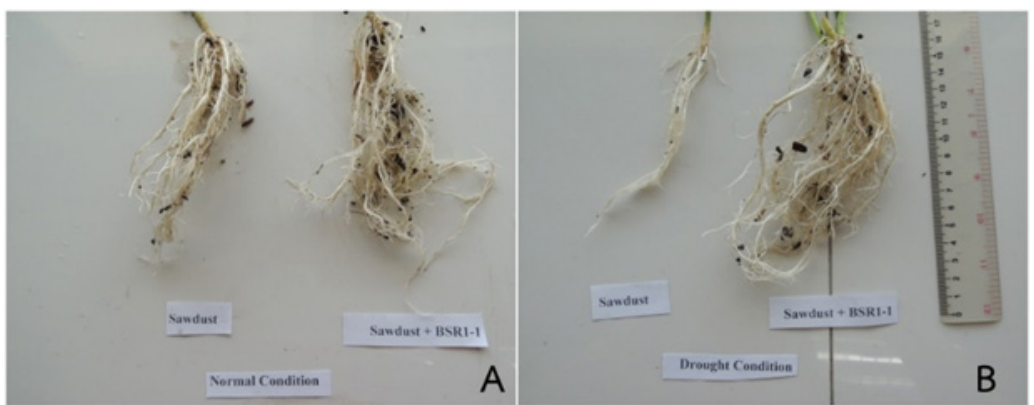

Figure 3 Characteristics of roots of aquatic morning glory grown under normal A) and drought conditions $\mathrm{B}$ ) in the absence and presence of Paenibacillus sp. BSR $1-1$ immobilized in sawdust.

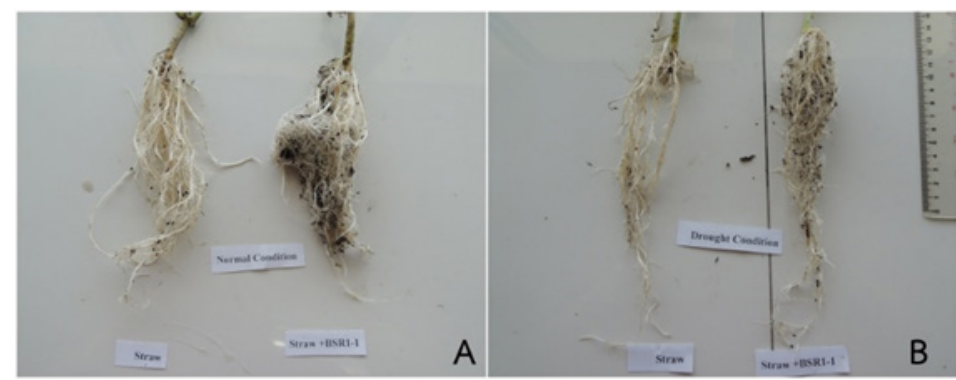

Figure 4 Characteristics of roots of aquatic morning glory grown under normal A) and drought conditions $\mathrm{B})$ in the absence and presence of Paenibacillus sp. BSR $\mathrm{BS}_{1-1}$ immobilized in rice straw.

Root growth and IAA-producing bacteria were the focus of this study because root growth is reduced first when a plant is exposed to drought stress. IAA was reported to increase plant growth under drought conditions. Exogenous IAA treatment increased the water content and chlorophyll content and improved the drought tolerance of white clover [27]. In addition, exogenous IAA could increase the water content and sugar content in wheat exposed to drought stress [28]. IAA-producing bacteria were also used to alleviate the effects of drought stress on plant growth by stimulating root proliferation and increasing

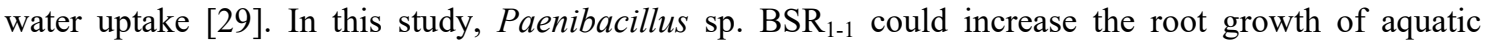
morning glory under drought conditions. In addition, aquatic morning glory roots under drought conditions without Paenibacillus sp. BSR $_{1-1}$ inoculation seemed to be less-branched and with a lower specific root length. When Paenibacillus sp. BSR $1-1$ was inoculated, the roots were more branching and the specific root length tended to increase. This was similar to that of aquatic morning glory under normal conditions. It is possible that the endogenous level of IAA, which could be disturbed by drought conditions, was modified with IAA produced by the bacterial inoculation and changed the root growth. Normally, auxin at a low concentration could induce root elongation and change the root architecture [1]. 
Table 2 Shoot and root growth of aquatic morning glory inoculation with Paenibacillus sp. BSR 1-1 immobilized in chopped coconut bract grown under normal conditions and drought conditions for 60 days. Data shown as mean \pm SE.

\begin{tabular}{|c|c|c|c|c|c|c|c|c|c|c|}
\hline \multirow{2}{*}{ Treatment } & \multicolumn{5}{|c|}{ Shoot Growth } & \multicolumn{5}{|c|}{ Root Growth } \\
\hline & $\begin{array}{l}\text { Shoot length } \\
\text { (cm) }\end{array}$ & $\begin{array}{l}\text { Shoot fresh } \\
\text { weight (g) }\end{array}$ & $\begin{array}{l}\text { Shoot dry } \\
\text { weight (g) }\end{array}$ & $\begin{array}{c}\text { Number of } \\
\text { shoots/plant }\end{array}$ & $\begin{array}{l}\text { Number of } \\
\text { leaves/plant }\end{array}$ & $\begin{array}{l}\text { Specific root } \\
\text { length }(\mathbf{m} / \mathbf{g})\end{array}$ & $\begin{array}{c}\text { Root/shoot } \\
\text { ratio }\end{array}$ & Root length (cm) & $\begin{array}{l}\text { Root fresh } \\
\text { weight (g) }\end{array}$ & $\begin{array}{c}\text { Root dry } \\
\text { weight (g) }\end{array}$ \\
\hline \multicolumn{11}{|l|}{ Normal condition } \\
\hline Coconut & $26.97 \pm 1.77 \mathrm{aB}$ & $6.44 \pm 1.15 \mathrm{aA}$ & $0.83 \pm 0.16 \mathrm{aA}$ & $2.31 \pm 0.24 \mathrm{aA}$ & $12.07 \pm 1.17 \mathrm{aA}$ & $0.44 \pm 0.04 \mathrm{aB}$ & $0.60 \pm 0.03 \mathrm{aA}$ & $16.73 \pm 1.11 \mathrm{bA}$ & $4.86 \pm 0.86 \mathrm{aA}$ & $0.47 \pm 0.08 \mathrm{aA}$ \\
\hline Coconut + BSR $_{1-1}$ & $36.22 \pm 4.53 \mathrm{aA}$ & $5.28 \pm 0.75 \mathrm{aA}$ & $0.61 \pm 0.07 \mathrm{aA}$ & $1.69 \pm 0.22 \mathrm{aA}$ & $7.44 \pm 0.52 \mathrm{aA}$ & $0.69 \pm 0.06 \mathrm{aB}$ & $0.58 \pm 0.01 \mathrm{aA}$ & $21.79 \pm 1.06 \mathrm{aA}$ & $5.19 \pm 0.67 \mathrm{aA}$ & $0.36 \pm 0.04 \mathrm{aA}$ \\
\hline \multicolumn{11}{|l|}{ Drought condition } \\
\hline Coconut & $47.01 \pm 6.48 \mathrm{aA}$ & $6.40 \pm 0.94 \mathrm{aA}$ & $0.41 \pm 0.05 \mathrm{aA}$ & $2.12 \pm 0.30 \mathrm{aA}$ & $7.75 \pm 0.92 \mathrm{aA}$ & $1.84 \pm 0.10 \mathrm{aA}$ & $0.18 \pm 0.01 \mathrm{bB}$ & $13.12 \pm 1.40 \mathrm{bA}$ & $1.66 \pm 0.34 \mathrm{aA}$ & $0.08 \pm 0.01 \mathrm{aB}$ \\
\hline Coconut + BSR $_{1-1}$ & $40.63 \pm 2.71 \mathrm{aA}$ & $7.31 \pm 1.61 \mathrm{aA}$ & $0.74 \pm 0.22 \mathrm{aA}$ & $1.93 \pm 0.23 \mathrm{aA}$ & $10.20 \pm 1.94 \mathrm{aA}$ & $1.31 \pm 0.25 \mathrm{aA}$ & $0.40 \pm 0.04 \mathrm{aB}$ & $17.71 \pm 1.52 \mathrm{aB}$ & $5.55 \pm 1.63 \mathrm{aA}$ & $0.28 \pm 0.08 \mathrm{aA}$ \\
\hline Condition & $* *$ & $\mathrm{~ns}$ & $\mathrm{~ns}$ & $\mathrm{~ns}$ & $\mathrm{~ns}$ & $* *$ & $* *$ & $* *$ & $\mathrm{~ns}$ & $* *$ \\
\hline Bacteria & ns & $\mathrm{ns}$ & $\mathrm{ns}$ & $\mathrm{ns}$ & $\mathrm{ns}$ & ns & $* *$ & $* *$ & $\mathrm{~ns}$ & $\mathrm{~ns}$ \\
\hline Condition*Bacteria & ns & ns & ns & $\mathrm{ns}$ & $\mathrm{ns}$ & $* *$ & $* *$ & $\mathrm{~ns}$ & $\mathrm{~ns}$ & $* *$ \\
\hline
\end{tabular}

Table 3 Shoot and root growth of aquatic morning glory inoculated with Paenibacillus sp. BSR $1-1$ immobilized with sawdust grown under normal conditions and drought conditions for 60 days. Data shown as mean $\pm \mathrm{SE}$.

\begin{tabular}{|c|c|c|c|c|c|c|c|c|c|c|}
\hline \multirow[b]{2}{*}{ Treatment } & \multicolumn{5}{|c|}{ Shoot Growth } & \multicolumn{5}{|c|}{ Root Growth } \\
\hline & $\begin{array}{l}\text { Shoot length } \\
\text { (cm) }\end{array}$ & $\begin{array}{l}\text { Shoot fresh } \\
\text { weight (g) }\end{array}$ & $\begin{array}{l}\text { Shoot dry } \\
\text { weight (g) }\end{array}$ & $\begin{array}{c}\text { Number of } \\
\text { shoots/plant }\end{array}$ & $\begin{array}{l}\text { Number of } \\
\text { leaves/plant }\end{array}$ & $\begin{array}{l}\text { Specific root } \\
\text { length }(\mathrm{m} / \mathrm{g})\end{array}$ & $\begin{array}{l}\text { Root/shoot } \\
\text { ratio }\end{array}$ & $\begin{array}{l}\text { Root length } \\
\text { (cm) }\end{array}$ & $\begin{array}{l}\text { Root fresh } \\
\text { weight (g) }\end{array}$ & $\begin{array}{l}\text { Root dry } \\
\text { weight (g) }\end{array}$ \\
\hline \multicolumn{11}{|l|}{ Normal condition } \\
\hline Sawdust & $26.73 \pm 2.11 \mathrm{aB}$ & $4.79 \pm 0.62 \mathrm{aA}$ & $0.76 \pm 0.08 \mathrm{aA}$ & $1.95 \pm 0.19 \mathrm{aA}$ & $8.68 \pm 0.88 \mathrm{aA}$ & $0.61 \pm 0.09 \mathrm{aB}$ & $0.90 \pm 0.04 \mathrm{aA}$ & $19.68 \pm 1.15 \mathrm{aA}$ & $6.75 \pm 1.09 \mathrm{aA}$ & $0.50 \pm 0.08 \mathrm{aA}$ \\
\hline Sawdust + BSR $_{1-1}$ & $27.05 \pm 1.74 \mathrm{aB}$ & $5.21 \pm 0.78 \mathrm{aA}$ & $0.67 \pm 0.13 \mathrm{aA}$ & $2.05 \pm 0.16 \mathrm{aA}$ & $8.26 \pm 0.66 \mathrm{aA}$ & $0.97 \pm 0.13 \mathrm{aB}$ & $0.55 \pm 0.03 \mathrm{bA}$ & $18.38 \pm 1.14 \mathrm{aA}$ & $4.44 \pm 0.93 \mathrm{aA}$ & $0.29 \pm 0.05 \mathrm{aA}$ \\
\hline \multicolumn{11}{|l|}{ Drought condition } \\
\hline Sawdust & $52.88 \pm 13.25 \mathrm{aA}$ & $4.10 \pm 1.14 \mathrm{aA}$ & $0.38 \pm 0.10 \mathrm{aB}$ & $2.00 \pm 0.32 \mathrm{aA}$ & $7.80 \pm 1.62 \mathrm{aA}$ & $2.40 \pm 0.05 \mathrm{abA}$ & $0.12 \pm 0.02 \mathrm{aB}$ & $10.62 \pm 2.23 \mathrm{aB}$ & $0.90 \pm 0.19 \mathrm{aB}$ & $0.04 \pm 0.01 \mathrm{aB}$ \\
\hline Sawdust + BSR $_{1-1}$ & $40.69 \pm 5.50 \mathrm{aA}$ & $5.99 \pm 0.92 \mathrm{aA}$ & $0.56 \pm 0.09 \mathrm{aA}$ & $2.08 \pm 0.24 \mathrm{aA}$ & $8.15 \pm 1.12 \mathrm{aA}$ & $2.86 \pm 0.59 \mathrm{aA}$ & $0.22 \pm 0.05 \mathrm{aB}$ & $16.02 \pm 1.59 \mathrm{aA}$ & $3.97 \pm 1.00 \mathrm{aA}$ & $0.16 \pm 0.06 \mathrm{aA}$ \\
\hline Condition & $* *$ & $\mathrm{~ns}$ & $* *$ & ns & ns & $* *$ & $* *$ & $* *$ & $* *$ & $* *$ \\
\hline Bacteria & ns & $\mathrm{ns}$ & $\mathrm{ns}$ & $\mathrm{ns}$ & $\mathrm{ns}$ & ns & $* *$ & $\mathrm{~ns}$ & $\mathrm{~ns}$ & ns \\
\hline Condition*Bacteria & ns & ns & ns & ns & ns & ns & $* *$ & $* *$ & $* *$ & $* *$ \\
\hline
\end{tabular}

Values with different lowercase letters were statistically different between bacterial inoculation and non-inoculation $(p<0.05)$; values with different capital letters were statistically different between the different conditions within the same inoculation type $(p<0.05) ; \mathrm{ns},{ }^{*},{ }^{* *}$ denote non-significance $(p>0.05)$, statistical significance $(p<0.05)$ and high statistical significance $(p<0.01)$ of each factor, respectively.

Table 4 Shoot growth of aquatic morning glory inoculated with Paenibacillus sp. BSR 1-1 $_{\text {immobilized }}$ with chopped rice straw grown under normal conditions and drought conditions for 60 days. Data shown as mean $\pm \mathrm{SE}$.

\begin{tabular}{|c|c|c|c|c|c|c|c|c|c|c|}
\hline \multirow{2}{*}{ Treatment } & \multicolumn{5}{|c|}{ Shoot Growth } & \multicolumn{5}{|c|}{ Root Growth } \\
\hline & $\begin{array}{l}\text { Shoot length } \\
\text { (cm) }\end{array}$ & $\begin{array}{l}\text { Shoot fresh } \\
\text { weight (g) }\end{array}$ & $\begin{array}{l}\text { Shoot dry } \\
\text { weight (g) }\end{array}$ & $\begin{array}{l}\text { Number of } \\
\text { shoots/plant }\end{array}$ & $\begin{array}{l}\text { Number of } \\
\text { leaves/plant }\end{array}$ & $\begin{array}{l}\text { Specific root } \\
\text { length }(\mathbf{m} / \mathbf{g})\end{array}$ & $\begin{array}{c}\text { Root/shoot } \\
\text { ratio }\end{array}$ & Root length (cm) & $\begin{array}{l}\text { Root fresh } \\
\text { weight (g) }\end{array}$ & $\begin{array}{c}\text { Root dry } \\
\text { weight (g) }\end{array}$ \\
\hline \multicolumn{11}{|l|}{ Normal condition } \\
\hline Straw & $26.77 \pm 1.72 \mathrm{aB}$ & $6.16 \pm 1.11 \mathrm{aA}$ & $0.55 \pm 0.07 \mathrm{aA}$ & $1.82 \pm 0.25 \mathrm{aA}$ & $10.18 \pm 1.02 \mathrm{aA}$ & $0.56 \pm 0.08 \mathrm{aB}$ & $1.02 \pm 0.04 \mathrm{aA}$ & $24.35 \pm 1.78 \mathrm{aA}$ & $5.74 \pm 0.84 \mathrm{aA}$ & $0.59 \pm 0.10 \mathrm{aA}$ \\
\hline Straw $+\mathrm{BSR}_{1-1}$ & $32.56 \pm 2.66 \mathrm{aA}$ & $5.41 \pm 0.51 \mathrm{aA}$ & $0.49 \pm 0.04 \mathrm{aA}$ & $1.94 \pm 0.21 \mathrm{aA}$ & $9.38 \pm 0.62 \mathrm{aA}$ & $0.63 \pm 0.06 \mathrm{aB}$ & $0.70 \pm 0.05 \mathrm{bA}$ & $18.51 \pm 0.88 \mathrm{aA}$ & $7.17 \pm 1.21 \mathrm{aA}$ & $0.36 \pm 0.06 \mathrm{aA}$ \\
\hline \multicolumn{11}{|l|}{ Drought condition } \\
\hline Straw & $44.88 \pm 5.87 \mathrm{aA}$ & $6.16 \pm 1.11 \mathrm{aA}$ & $0.53 \pm 0.13 \mathrm{aA}$ & $1.82 \pm 0.23 \mathrm{aA}$ & $8.91 \pm 1.38 \mathrm{aA}$ & $1.38 \pm 0.10 \mathrm{aA}$ & $0.22 \pm 0.01 \mathrm{aB}$ & $13.54 \pm 1.43 \mathrm{aB}$ & $1.77 \pm 0.42 \mathrm{aB}$ & $0.11 \pm 0.02 \mathrm{aB}$ \\
\hline Straw + BSR $_{1-1}$ & $37.15 \pm 3.82 \mathrm{aA}$ & $7.88 \pm 1.20 \mathrm{aA}$ & $0.68 \pm 0.10 \mathrm{aA}$ & $2.07 \pm 0.23 \mathrm{aA}$ & $8.33 \pm 0.96 \mathrm{aA}$ & $1.76 \pm 0.41 \mathrm{aA}$ & $0.27 \pm 0.04 \mathrm{aB}$ & $18.08 \pm 1.19 \mathrm{aA}$ & $4.14 \pm 0.95 \mathrm{aB}$ & $0.22 \pm 0.06 \mathrm{aA}$ \\
\hline Condition & $* *$ & ns & ns & ns & ns & $* *$ & $* *$ & $* *$ & $* *$ & $* *$ \\
\hline Bacteria & ns & ns & ns & ns & ns & ns & $* *$ & ns & ns & ns \\
\hline Condition*Bacteria & ns & ns & ns & ns & ns & ns & $* *$ & $* *$ & ns & * \\
\hline
\end{tabular}

Values with different lowercase letters were statistically different between bacterial inoculation and non-inoculation $(p<0.05)$; values with different capital letters were statistically different between the different conditions within the same inoculation type $(p<0.05)$; ns, * ** denote non-significance $(p>0.05)$, statistical significance $(p<0.05)$ and high statistical significance $(p<0.01)$ of each factor, respectively. 
Table 5 Chlorophyll content in leaves of aquatic morning glory inoculated with Paenibacillus sp. BSR 1-1 $_{1}$ immobilized with chopped coconut bract, sawdust and chopped rice straw grown under normal conditions and drought conditions for 60 days. Data shown as mean $\pm \mathrm{SE}$.

\begin{tabular}{|c|c|c|c|c|}
\hline Treatment & $\begin{array}{c}\text { Chlorophyll a } \\
(\mathrm{mg} / \mathrm{mL})\end{array}$ & $\begin{array}{c}\text { Chlorophyll b } \\
(\mathrm{mg} / \mathrm{mL})\end{array}$ & $\begin{array}{c}\text { Total chlorophyll } \\
(\mathrm{mg} / \mathrm{mL})\end{array}$ & $\begin{array}{c}\text { Chlorophyll a/ } \\
\text { chlorophyll b ratio }\end{array}$ \\
\hline \multicolumn{5}{|l|}{ Normal condition } \\
\hline Coconut & $17.24 \pm 0.65 \mathrm{aA}$ & $7.92 \pm 0.38 \mathrm{aA}$ & $25.15 \pm 0.71 \mathrm{aA}$ & $2.21 \pm 0.14 \mathrm{aA}$ \\
\hline \multicolumn{4}{|l|}{ Drought condition } & $2.17 \pm 0.14 \mathrm{aA}$ \\
\hline Coconut & $18.14 \pm 1.48 \mathrm{aA}$ & $8.57 \pm 0.59 \mathrm{aA}$ & $26.70 \pm 1.89 \mathrm{aA}$ & $2.14 \pm 0.16 \mathrm{aA}$ \\
\hline Coconut + BSR $_{1-1}$ & $18.98 \pm 1.18 \mathrm{aA}$ & $7.97 \pm 0.76 \mathrm{aA}$ & $26.94 \pm 1.15 \mathrm{aA}$ & $2.52 \pm 0.27 \mathrm{aA}$ \\
\hline Condition & $\mathrm{ns}$ & $\mathrm{ns}$ & ns & $\mathrm{ns}$ \\
\hline Bacteria & ns & $\mathrm{ns}$ & ns & ns \\
\hline Condition*Bacteria & ns & ns & ns & ns \\
\hline \multicolumn{5}{|l|}{ Normal condition } \\
\hline Sawdust & $17.84 \pm 1.77 \mathrm{aA}$ & $8.30 \pm 0.32 \mathrm{aA}$ & $26.14 \pm 2.02 \mathrm{aA}$ & $2.13 \pm 0.15 \mathrm{aA}$ \\
\hline \multicolumn{4}{|l|}{ Drought condition } & $1.81 \pm 0.25 \mathrm{aA}$ \\
\hline Sawdust & $22.51 \pm 3.27 \mathrm{aA}$ & $10.46 \pm 1.25 \mathrm{aA}$ & $32.96 \pm 4.46 \mathrm{aA}$ & $2.14 \pm 0.12 \mathrm{aA}$ \\
\hline Sawdust + BSR $_{1-1}$ & $18.19 \pm 1.65 \mathrm{aA}$ & $8.28 \pm 0.83 \mathrm{aA}$ & $26.47 \pm 2.41 \mathrm{aA}$ & $2.22 \pm 0.12 \mathrm{aA}$ \\
\hline Condition & ns & ns & ns & ns \\
\hline Bacteria & ns & ns & ns & ns \\
\hline Condition*Bacteria & ns & ns & ns & ns \\
\hline \multicolumn{5}{|l|}{ Normal condition } \\
\hline Straw & $13.28 \pm 1.32 \mathrm{aA}$ & $6.83 \pm 0.42 \mathrm{bA}$ & $20.10 \pm 1.69 \mathrm{aB}$ & $1.92 \pm 0.11 \mathrm{aA}$ \\
\hline \multicolumn{4}{|l|}{ Drought condition } & $1.67 \pm 0.07 \mathrm{aA}$ \\
\hline Straw & $17.26 \pm 1.53 \mathrm{aA}$ & $8.81 \pm 0.78 \mathrm{aA}$ & $25.87 \pm 2.22 \mathrm{aA}$ & $1.94 \pm 0.10 \mathrm{aA}$ \\
\hline Straw + BSR $_{1-1}$ & $16.74 \pm 1.59 \mathrm{aA}$ & $9.31 \pm 0.74 \mathrm{aA}$ & $26.04 \pm 2.32 \mathrm{aA}$ & $1.78 \pm 0.06 \mathrm{aA}$ \\
\hline Condition & $\mathrm{ns}$ & ns & $\mathrm{ns}$ & $\mathrm{ns}$ \\
\hline Bacteria & ns & $*$ & ns & ns \\
\hline Condition*Bacteria & ns & ns & ns & ns \\
\hline
\end{tabular}

Values with different lowercase letters were statistically different between bacterial inoculation and noninoculation $(p<0.05)$; values with different capital letters were statistically different between the different conditions within the same inoculation type $(p<0.05)$; ns, $*$, ** denote non-significance $(p>$ $0.05)$, statistical significance $(p<0.05)$ and high statistical significance $(p<0.01)$ of each factor, respectively.

Total chlorophyll, chlorophyll a and chlorophyll b contents in aquatic morning glory leaves remained constant under normal conditions and drought conditions. Following soil inoculation with Paenibacillus sp. $\mathrm{BSR}_{1-1}$, the chlorophyll content in the leaves of aquatic morning glory was not significantly different when compared with non-inoculated treatments for both drought conditions and normal conditions. Normally, drought conditions reduced the photosynthesis rate, changed the photosynthetic pigment and damaged the photosynthetic apparatus. This was caused by the induction of oxidation stress and pigment degradation in the chloroplast [7,29]. The drought conditions in this study did not significantly reduce the chlorophyll content in the leaves of aquatic morning glory. This may be due to the drought conditions used in this study not representing heavy stress that could destroy chlorophyll content in aquatic morning glory leaves. Irrigation of the plant once every other day may be sufficient for maintaining the chlorophyll contents in aquatic morning glory leaves. In addition, increased, diminished or unchanged chlorophyll content in plant leaves under drought conditions have been reported in other plants [31-33]. The duration of drought and the asperity of drought were a critical factor to determine the level of chlorophyll in plants $[32,33]$. However, possible mechanisms of plant growthpromoting bacteria to alleviate drought stress and chlorophyll damage in plants may be due to several mechanisms, including exopolysaccharides production [1], indole-3-acetic acid production [1], ACC deaminase production and induction of the osmolyte accumulation and antioxidants activity [8]. 
Especially, the ability to produce exopolysaccharides by Paenibacillus sp. $\mathrm{BSR}_{1-1}$ may be an advantage for the growth of aquatic morning glory under drought conditions. Exopolysaccharide-producing bacteria have been reported to increase the water holding capacity in soil. This characteristic of the exopolysaccharide can reduce the adverse effects of drought stress on the plant [1].

\section{Conclusions}

Using Paenibacillus sp. BSR $_{1-1}$ as a bio-inoculant to maintain the growth of aquatic morning glory under drought conditions is possible due to its ability to produce IAA, ammonia and exopolysaccharide. Using a Paenibacillus sp. BSR $1-1$ culture significantly supported the root growth of aquatic morning glory, thereby the specific root length of aquatic morning glory grown under both normal and drought conditions was usually higher than that grown without any bacterial inoculation. The use of Paenibacillus sp. $\mathrm{BSR}_{1-1}$ to maintain the growth of other plants, as determined using field experiments, should be tested in the future.

\section{Acknowledgements}

This research project was financially supported by Mahasarakham University Grant Year 2021 under Grant No. 6408010/2564.

\section{References}

[1] OB Ojuederie, OS Olanrewaju and OO Babalola. Plant growth promoting rhizobacterial mitigation of drought stress in crop plants: Implication for sustainable agriculture. Agronomy 2019; 9, 712.

[2] D Zhiña, M Montenegro, L Montalván, D Mendoza, J Contreras, L Campozano and A Alex. Climate change influences of temporal and spatial drought variation in the Andean high mountain basin. Atmosphere 2019; 10, 558.

[3] CT Tan and JJ Pereira. Climate change adaptation: An overview of Southeast Asia. Asian J. Environ. Disast. Manag. 2011; 2, 371-95.

[4] X Niu, L Song, Y Xiao and W Ge. Drought-tolerance plant growth-promoting rhizobacteria associated with foxtail millet in a semi-arid agroecosystem and their potential in alleviating drought stress. Front. Microbiol. 2018; 8, 2580.

[5] Office of natural calamity and agricultural risk prevention, Available at: http://irw101.ldd.go.th/index.php/2017-05-23-02-00-40/2017-05-23-02-00-39, accessed October, 2020 .

[6] Thai meteorological department, Available at: https://www.tmd.go.th/info/info.php?FileID=71, accessed August 2020.

[7] M Farooq, A Wahid, N Kobayashi, D Fujita and SMA Basra. Plant drought stress: effects, mechanisms and management. Agron. Sustain. Dev. 2009; 29, 185-202.

[8] SSKP Vurukonda, S Vardharajula, M Shrivastava and A Skz. Enhancement of drought stress tolerance in crops by plant growth promoting rhizobacteria. Microbiol. Res. 2016; 184, 13-24.

[9] HA Hussain, S Hussain, A Khaliq, U Ashraf, SA Anjum, S Men and LW Ang. Chilling and Drought stresses in crop plants: Implications, cross talk, and potential management opportunities. Front. Plant Sci. 2012; 9, 393.

[10] R Stikić, Z Jovanović and L Prokić. Mitigation of plant drought stress in a changing climate. Botanica Serbica 2014; 38, 35-42.

[11] S Delshadi, M Ebrahimia and E Shirmohammadia. Plant growth promoting bacteria effects on growth, photosynthetic pigments and root nutrients uptake of Avena sativa L. under drought stress. Desert 2017; 22, 107-16.

[12] MD Jochum, KL McWilliams, EJ Borrego, MV Kolomiets, G Niu, GN Pierson and YK Jo. Bioprospecting plant growth promoting rhizobacteria that mitigate drought stress in grasses. Front. Microbiol. 2019; 10, 2106.

[13] S Viscardi, V Ventorino, P Duran, A Maggio, SD Pascale, ML Mora and O Pepe. Assessment of plant growth promoting activities and abiotic stress tolerance of Azotobacter chroococcum for a potential use in sustainable agriculture. J. Soil. Sci. Plant Nut. 2016; 16, 848-63.

[14] KN Prasad, GR Shivamurthy and SM Aradhya. Ipomoea aquatic, an underutilized green leafy vegetable: A review. Int. J. Bot. 2008; 4, 123-129. 
[15] L Tang, Y Hamid, A Zehra, ZA Sahito, Z He, MB Khan, Y Feng and X Yang. Mechanisms of water regime effects on uptake of cadmium and nitrate by two ecotypes of water spinach (Ipomoea aquatic Forsk.) in contaminated soil. Chemosphere 2020; 246, 125798.

[16] K Somtrakoon, A Sangdee and W Chouychai. Effect of Streptomyces sp. St1 on growth of and potential to stimulate anthracene removal by sunn hemp (Crotalaria juncea) grown in anthracenecontaminated soil. Songklanakarin J. Sci. Tech. 2021; 43, 615-22.

[17] L Maturin and JT Peeler. BAM chapter 3: Aerobic plate count, Available at https://www.fda.gov/food/laboratory-methods-food/bam-chapter-3-aerobic-plate-count, accessed May 2021.

[18] V Lakshminarayanan, $\mathrm{R}$ Ponnuswamy and $\mathrm{B}$ Rengaraju. Screening, purification and characterization of ß-glucan from a novel strain Bacillus cereus LVK13 (KC 898956). Int. J. ChemTech Res. 2015; 8, 1156-62.

[19] F Ahmad, I Ahmad and MS Khan. Screening of free-living rhizospheric bacteria for their multiple plant growth promoting activities. Microbiol. Res. 2008; 163, 178-81.

[20] D Chandra, R Srivastava, BR Glick and AK Sharma. Drought-tolerant Pseudomonas spp. improve the growth performance of finger millet (Eleusine coracana (L.) Gaertn.) under non-stressed and drought-stressed conditions. Pedosphere 2018; 28, 227-40.

[21] X Huang, Y El-Alawi, DM Penrose, BR Glick and BM Greenberg. Response of three grass species to creosote during phytoremediation. Environ. Pollut. 2004; 130, 453-63.

[22] K Somtrakoon, A Sangdee and W Chouychai. Roles of plant growth promoting bacteria on growth of ornamental plants grown in anthracene-spiked soil. J. Agr. Res. Ext. 2019; 36, 11-22.

[23] JDV Elsas, GF Duarte, AS Rosado and K Smalla. Microbiological and molecular biological methods for monitoring microbial inoculants and their effects in the soil environment. J. Microbiol. Meth. 1998; 32, 133-54.

[24] T Bouchez, D Patureau, P Dabert, S Juretschko, J Dore, P Delgenes, R Moletta and M Wagner. Ecological study of a bioaugmentation failure. Environ. Microbiol. 2000; 2, 179-90

[25] W Dejonghe, N Boon, D Seghers, EM Top and W Verstraete. Bioaugmentation of soils by increasing microbial richness: Missing links. Environ. Microbiol. 2001; 3, 649-57

[26] MS Santos, MA Nogueira and M Hungria. Microbial inoculants: reviewing the past, discussing the present and previewing an outstanding future for the use of beneficial bacteria in agriculture. $A M B$ Express 2019; 9, 205.

[27] Y Zhang, Y Li, MJ Hassan, Z Li and Y Peng. Indole-3-acetic acid improves drought tolerance of white clover via activating auxin, abscisic acid and jasmonic acid related genes and inhibiting senescence genes. BMC Plant Biol. 2020; 20, 150.

[28] N Muhammad, Hakim, UM Quraishi, HJ Chaudhary and MFH Munis. Indole-3-acetic acid induces biochemical and physiological changes in wheat under drought stress condition. Philippine Agr. Sci. 2016; 99, 19-24.

[29] C Dimkpa, T Weinand and F Asch. Plant-rhizobacteria interactions alleviate abiotic stress condition. Plant Cell Environ. 2009; 32, 1682-94.

[30] S Munné-Bosch, T Jubany-Marí and L Alegre. Drought-induced senescence is characterized by a loss of antioxidant defences in chloroplasts. Plant Cell Environ. 2001; 24, 1312-7.

[31] M Naveed, B Mitter, TG Reichenauer, K Wieczorek and A Sessitsch. Increased drought stress resilience of maize through endophytic colonization by Burkholderia phytofirmans PsJN and Enterobacter sp. FD17. Environ. Exp. Bot. 2014; 97, 30-9.

[32] A Kpyoarissis, Y Petropoulou and Y Manetas. Summer survival of leaves in a soft-leaved shrub (Phlomis fruticose L., Labiatae) under Mediterranean field conditions: avoidance of photoinhibitory damage through decreased chlorophyll contents. J. Exp. Bot.1995; 46, 1825-31.

[33] A Mafakheri, A Siosemardeh, B Bahramnejad, PC Struik and Y Sohrabi. Effect of drought stress on yield, proline and chlorophyll contents in three chickpea cultivars. Aust. J. Crop Sci. 2010; 4, 580-5. 